\title{
Teaching NeuroImages: Hypomyelinating leukodystrophy with generalized dystonia
}

S. Vinayagamani, MD, Sruthi S. Nair, MD, DM, and Soumya Sundaram, MD, DM

Neurology ${ }^{\circledR}$ 2020;94:e335-e336. doi:10.1212/WNL.0000000000008827

Figure Hypomyelination with atrophy of basal ganglia and cerebellum

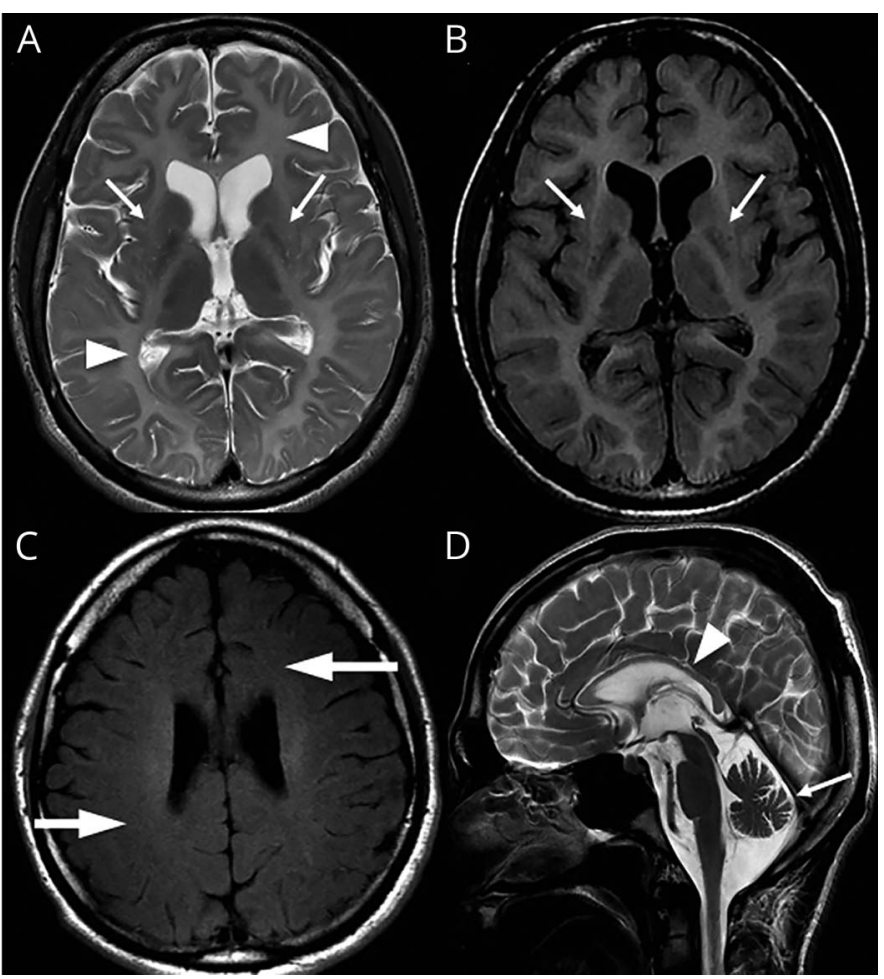

Axial T2 (A), T2 fluid-attenuated inversion recovery $(B)$, and $\mathrm{T} 1$ weighted (C) images show diffuse symmetrical white matter hyperintensity (arrowheads), small to absent putamen (arrows), and isointense signal of white matter suggestive of hypomyelination (thick arrows); sagittal T2-weighted image (D) shows atrophy of corpus callosum (arrowhead) and cerebellar vermis (arrow).
A 16-year-old boy, born of nonconsanguineous parentage, had an uneventful birth history and mild global developmental delay. He had progressive gait disturbances since 2 years of age. Examination revealed generalized dystonia, scanning speech, pendular nystagmus, cerebellar ataxia, and spasticity. MRI brain showed features of hypomyelination with atrophy of the basal ganglia and cerebellum (H-ABC) (figure).

Next-generation exome sequencing showed a heterozygous mutation in exon 4 of TUBB4A (c.731G>A), confirming the diagnosis. The presence of generalized dystonia and atrophic/absent putamen are the 2 features that distinguish $\mathrm{H}-\mathrm{ABC}$ from the other hypomyelinating leukodystrophies, such as Pelizaeus-Merzbacher disease, Salla disease, and Tay syndrome. ${ }^{1,2}$

\section{Correspondence}

Dr. Sundaram

ssdr.soumya@gmail.com

\section{MORE ONLINE}

\section{$\rightarrow$ Teaching slides}

links.lww.com/WNL/

B33

From the Department of Imaging Sciences and Intervention Radiology (S.V.) and Comprehensive Care Centre for Neurodevelopmental Disorders (S.S.), Department of Neurology (S.S.N.), Sree Chitra Tirunal Institute for Medical Sciences and Technology, Trivandrum, India.

Go to Neurology.org/N for full disclosures. Funding information and disclosures deemed relevant by the authors, if any, are provided at the end of the article. 


\section{Author contributions}

S. Vinayagamani: study design, acquisition of data, and drafting of the manuscript. S.S. Nair: interpretation of data and critical revision of the manuscript. S. Sundaram: study concept, design, and critical revision of the manuscript.

\section{Study funding}

No targeted funding reported.

\section{Disclosure}

The authors report no disclosures relevant to the manuscript. Go to Neurology.org/N for full disclosures.

\section{References}

1. van der Knaap MS, Naidu S, Pouwels PJ, et al. New syndrome characterized by hypomyelination with atrophy of the basal ganglia and cerebellum. AJNR Am J Neuroradiol 2002;23:1466-1474.

2. Hamilton EM, Polder E, Vanderver A, et al. Hypomyelination with atrophy of the basal ganglia and cerebellum: further delineation of the phenotype and genotypephenotype correlation. Brain 2014;137:1921-1930. 


\section{Neurology}

Teaching NeuroImages: Hypomyelinating leukodystrophy with generalized dystonia S. Vinayagamani, Sruthi S. Nair and Soumya Sundaram

Neurology 2020;94;e335-e336

DOI 10.1212/WNL.0000000000008827

This information is current as of January 20, 2020

Updated Information \& Services

References

Subspecialty Collections

Permissions \& Licensing

Reprints including high resolution figures, can be found at: http://n.neurology.org/content/94/3/e335.full

This article cites 2 articles, 0 of which you can access for free at: http://n.neurology.org/content/94/3/e335.full\#ref-list-1

This article, along with others on similar topics, appears in the following collection(s):

\section{Dystonia}

http://n.neurology.org/cgi/collection/dystonia

Information about reproducing this article in parts (figures,tables) or in its entirety can be found online at:

http://www.neurology.org/about/about_the_journal\#permissions

Information about ordering reprints can be found online:

http://n.neurology.org/subscribers/advertise

Neurology ${ }^{\circledR}$ is the official journal of the American Academy of Neurology. Published continuously since 1951, it is now a weekly with 48 issues per year. Copyright (C 2020 American Academy of Neurology. All rights reserved. Print ISSN: 0028-3878. Online ISSN: 1526-632X.

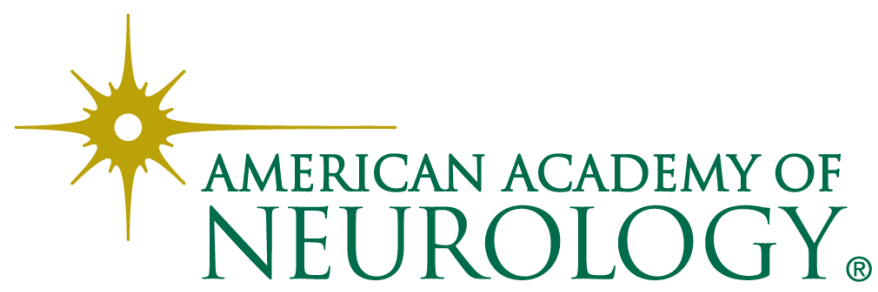

